\title{
Аналіз та систематизація підходів до розуміння поняття “гібридної війни"
}

\author{
Анатолій Лойшин ${ }^{1}$ A; Іван Ткач 2 А; Микола Ткач ${ }^{3}$ А; Віталій Шевчук 4 А \\ А Національний університет оборони України імені Івана Черняховського, пр-кт Повітрофлотський 28, м. Київ, 03049, Україна
}

Received: January 30, 2020 | Revised: February 20, 2021 | Accepted: February 28, 2021

DOI: $10.33445 / s d s .2021 .11 .1 .15$

\begin{abstract}
Анотація
У статті узагальнено аргументи та контраргументи в межах наукової дискусії з питання феномену гібридної війни з урахуванням втягнення України Російською Федерацією у стан неоголошеної гібридної війни. Основними цілями дослідження $€$ аналіз та систематизація підходів до розуміння природи гібридної війни вітчизняними та іноземними науковцями, узагальнення ї̈ ключових особливостей і формулювання синтезованого визначення 3 урахуванням триваючої агресії проти України.

На підставі систематизації широкого кола наукових праць та підходів до вирішення проблеми дослідження природи гібридної війни виявлено тенденцію до зростання уваги серед науковців до ії дослідження.

Актуальність вирішення цієї наукової проблеми в українському вимірі полягає у безпосередньо втягненні України у площину неоголошеної війни.

Проблематику гібридної війни у статті досліджено в такій логічній послідовності: ретроспективно проаналізовано розвиток, формування та ідентифікацію змісту термінів “гібридна війна", "гібридні засоби ведення війни"; встановлено взаємозв'язок між гібридною війною, широким колом їі методів та інструментів; виокремлено ознаки гібридної війни у низці війн та конфліктів; проаналізовано тенденції до регламентації проблематики гібридної війни не лише у наукових джерелах, а й у нормативно-правових документах; проаналізовано підходи до визначення змісту і природи гібридної війни, що відображені у публікаціях вітчизняних науковців, відповідно до чого сформульовано універсальне тлумачення терміна, та підтверджено думку про його "парасолькове" значення. Методичним інструментарієм дослідження стали методи аналізу, синтезу та системного підходу, часовими межами частково охоплено історичні події з часів Пелопоннеської війни до сьогодення. Об'єктом дослідження обрано війну у всіх їі проявах, оскільки саме гібридна війна є похідною від звичайної конвенційної війни.

У статті надано результати емпіричного аналізу підходів до розуміння природи гібридної війни, які показують, необхідність подальших досліджень у предметній сфері 3 урахуванням останніх подій в Україні. Результати дослідження можуть бути корисними для науковців та управлінців, які досліджують проблеми національної безпеки, розбудови сектору безпеки й оборони, оборонного планування.
\end{abstract}

Ключові слова: війна, гібридна війна, гібридні загрози.

\section{Постановка проблеми}

Станом на сьогодні Україна сьомий рік втягнута у неоголошену війну, яку веде Російська Федерація. За період збройного конфлікту загинули тисячі українців, тисячі українських сімей вимушені були залишити свої домівки та рятуватися від наслідків

\footnotetext{
${ }^{1}$ Corresponding author: доктор філософії, старший викладач кафедри економіки та фінансового забезпечення, е-таil: aloishyn@gmail.com, ORCID: 0000-0003-2769-9336

2 д.е.н., професор, Начальник центру оборонного менеджменту, e-mail: tkachivan9@gmail.com, ORCID: 0000-0001-5547-6303

${ }^{3}$ к.т.н., начальник кафедри оборонного менеджменту, e-mail: nyck1985@ukr.net, ORCID: 0000-0002-8832-1268

${ }^{4}$ к.в.н., начальник науково-дослідної лабораторії проблем воєнної безпеки держави, e-mail: shevchuksnbo@ukr.net, ORCID: 0000-0002-8532-739x
} 
відкритої агресії противника. Весь світ є свідком агресивних дій з боку Російської Федерації, яка всупереч укладеним міжнародним договорам та угодам, не визнає верховенства права у сучасному цивілізованому світі. Саме неоголошена війна, що ведеться не лише за допомогою зброї, а й з широким застосуванням політичних, економічних, соціальних, інформаційних та інших інструментів викликає необхідність постійного дослідження зазначеного процесу не лише у воєнній науці, а й в інших сферах та напрямах наукових досліджень. за своєю Сутність гібридної агресії полягає у поєднанні військових і не військових інструментів. Прусський військовий теоретик та історик К. Клаузевіц зазначав, що війна - це "більше, ніж хамелеон", який безперервно адаптується до особливостей кожної епохи [1].

Починаючи з 3500 р. до н.е. людство прожило без війн лише 292 роки. У XIX ст. відбулися 14 воєн із втратами від 100 тис. осіб і більше у кожній, у тому числі дві війни, в яких загинули понад 1 млн осіб [2].

Актуальність наукового дослідження всесвіту гібридних воєн не $€$ новим у науці. Римська епоха, хрестові походи, період реформації у Європі або імперська історія Великій Британії містять елементи того, що нині вважається війною четвертого покоління [3].

Разом 3 тим постійна трансформація політичних, економічних та соціальних процесів, що супроводжується стрімким розвитком науки і техніки потребує своєчасного реагування на нові виклики та загрози у вигляді “чорних лебедів" [4], як запропонував Н. Талеб тлумачити подій, які за змістом не передбачувані через складність прогнозування характер, мають місце час від часу різну періодичність настання.

\section{Аналіз останніх досліджень та публікацій}

Аналізу сучасного стану досліджень у сфері гібридних війн та власне ії феномену присвячено чимало іноземних та вітчизняних наукових праць. Поштовхом у дослідженні проблематики гібридних воєн стали праці Р. Волкера, В. Герасимова, Ф. Гоффмана, Т. Гюбера, Г. Іссерсона, Ф. Каппена, Д. Кілкаллена, Є. Е. Месснера, Д. Маккуена, В. Немета та інших. Широко висвітлено зазначену проблематику у працях науковців Національного інституту стратегічних досліджень (В. Горбуліна, Г. Яворської, О. Їжака, В. Бегми та інших), Національного університету оборони України імені Івана Черняховського (В. Телелима, Д. Музиченка,
Ю. Пунди та ін.), Національної академії Служби безпеки України (О. Акульшина, О. Заруби, Л. Компанцевої, С. Кудінова, Н. Слухай, О. Снитка та ін.).

Неоціненний вклад у дослідження гібридної війни з боку Російської Федерації зробили: А. Дацюк, Г. Жекало, О. Заруба, І. Заступ, О. Золотар, Ю. Канарський, Н. Карпчук, 3. Коваль, Л. Компанцева, С. Кудінов, В. Ліпкан, Є. Магда, Л. Нікіфорова, В. Петрик, Г. Пєвцов, А. Поплавський, О. Пошедін, Ю. Радковець, І. Рущенко, Д. Сидоренко, Н. Слухай, О. Снитко, М. Требін, Л. Шипілова, А. Шиян та інші науковці.

\section{Постановка завдання}

Метою статті $\epsilon$ аналіз та систематизація підходів до розуміння природи гібридної війни вітчизняними й іноземними науковцями, узагальнення ключових особливостей, формулювання синтезованого визначення 3 урахуванням агресії РФ проти України.

Під час вивчення проблеми було ряд наукових методів теоретичного та емпіричного дослідження, а саме: порівняння (у процесі зіставлення наявних визначень терміна “гібридна війна”), аналізу (під час опрацювання джерел, дослідження складових визначення), синтезу (у ході об'єднання ключових елементів та результатів дослідження), а також системного підходу у предметній сфері дослідження.

Для забезпечення досягнення мети статті пропонуємо провести декомпозицію мети 
наукового дослідження у такому порядку:

спочатку, проаналізувати розвиток, формування та ідентифікацію змісту терміна “гібридна війна"; потім, проаналізувати формулювання сучасних тлумачень терміна "гібридна війна"; нарешті, сформулювати універсальне визначення терміна “гібридна війна”.

\section{Виклад основного матеріалу}

Сам термін “гібрид/гібридний" $\epsilon$ запозиченим словом (hybrid, 3 англ. "змішаний"), що позначає сукупність неоднорідних елементів. Відповідно до словника української мови [5] "гібридний" означає те, що складається "з чого-небудь різного, різнорідного”. Також термін “гібрид” має первісно біологічне значення зрощування двох чи більше різних організмів [6]. Термін "гібридна війна" / "hybrid war" прийшов в Україну зі США з початком збройної агресії Російської Федерації проти нашої держави. До початку цієї збройної агресії в науці широко застосовували термін "hybrid warfare" - "гібридні засоби ведення війни" [7,
C. 29]. Відмінність між термінами “війна" та "засоби ведення війни" $€$ беззаперечною у контексті розгляду їх тлумачення в одній площині. Термін "hybrid warfare" запропонував американський військовий Р. Волкер який досліджував природу війни, та аналізував пов'язаність звичайної війни із проведенням спеціальних операцій [8]. У ході дослідженні ми проаналізовали ряд іноземних та вітчизняних джерел і для показу послідовності ідентифікації феномену “гібридна війна" та ключових стадій еволюції визначення, склали таблицю у якій ретроспективно відображено розвиток основних тез для розуміння природи гібридної війни (Табл. 1).

Таблиця 1 - Розвиток, формування та ідентифікація змісту терміна "гібридна війна" /"гібридні засоби ведення війни"

\begin{tabular}{|c|c|c|}
\hline Рік & Автор & Основна теза \\
\hline 1940 & Г. Іссерсон & $\begin{array}{l}\text { Актуалізація прихованих партизанських рухів, громадсько-політичних } \\
\text { організацій, їх мобілізація що сукупно узаконюють атакуючі дії }\end{array}$ \\
\hline 1960 & Є. Е. Месснер & $\begin{array}{l}\text { Широке застосування незаконних, нерегулярних збройних формувань } 3 \\
\text { одночасним впливом на свідомість населення у країні-противнику } \\
\text { виведення психології бунтівних мас на перший план }\end{array}$ \\
\hline 1996 & Т. Гюбер & $\begin{array}{l}\text { Формулювання терміна “сполучена війна"/ “compound war”, яким } \\
\text { передбачено застосування, крім регулярних військових формувань, } \\
\text { іррегулярних військових формувань (повстанських сил); }\end{array}$ \\
\hline 1998 & Р. Волкер & $\begin{array}{l}\text { Формулювання пов'язаності між звичайною війною та проведенням } \\
\text { спеціальних операцій }\end{array}$ \\
\hline 2002 & В. Немет & $\begin{array}{l}\text { Поширення гібридних спільнот, що спричиняє гібридного ведення війни } \\
\text { та потребує розвитку гібридних сил }\end{array}$ \\
\hline 2007 & Ф. Гоффман & “Гібридна війна” поєднує різноманіття методів ведення війни \\
\hline 2008 & Д. Маккуен & $\begin{array}{l}\text { “Гібридна війна" - метод асиметричної війни, яка триває у трьох } \\
\text { площинах - між населенням зони конфлікту, тиловим населенням і } \\
\text { міжнародним співтовариством }\end{array}$ \\
\hline 2009 & Ф. Гоффман & $\begin{array}{l}\text { “Гібридна війна” - особливий випадок “сполученої війни”, в якій } \\
\text { досягаються більшої інтеграції різнорідних інструментів на нижчому рівні }\end{array}$ \\
\hline 2012 & Ф. Гоффман & $\begin{array}{l}\text { “Гібридна війна” поєднує звичайні озброєння, іррегулярну тактику, } \\
\text { тероризм, кримінальні дії }\end{array}$ \\
\hline 2013 & В. Герасимов & $\begin{array}{l}\text { Зростання ролі невоєнних способів у досягненні політичних істратегічних } \\
\text { цілей, зміщення методів протиборства у бік широкого застосування } \\
\text { політичних, економічних, інформаційних, гуманітарних та інших } \\
\text { невоєнних заходів, реалізованих із залученням протестного потенціалу } \\
\text { населення }\end{array}$ \\
\hline
\end{tabular}


ISSN 2522-9842 Journal of Scientific Papers "Social Development and Security", Vol. 11, No. 1, - 2021

\begin{tabular}{|c|l|l|}
\hline \hline Рік & \multicolumn{1}{|c|}{ Автор } & \multicolumn{1}{c|}{ Основна теза } \\
\hline 2014 & Початок агресії Російської Федерації проти України \\
\hline 2014 & В. М. Телелим & $\begin{array}{l}\text { 3міщення акцентів у бік уникнення прямих зіткнень між збройними } \\
\text { силами конфліктуючих держав }\end{array}$ \\
\hline 2017 & В. П. Горбулін & $\begin{array}{l}\text { Одночасне застосування звичайних і нетрадиційних засобів в адаптивний } \\
\text { спосіб для досягнення своїх цілей }\end{array}$ \\
\hline
\end{tabular}

Джерело: складено автором на основі джерел [9-19].

Один із найвідоміших науковців у галузі проблематики гібридної війни Ф. Гоффман у праці "Conflicts in the 21st Century: The Rise of Hybrid Wars" зазначає, що гібридні загрози містять повний спектр різних способів ведення війни, у тому числі звичайні можливості, нерегулярну тактику, терористичні акти, поєднані з насильством та примусом, злочинні розлади.

Також, Ф. Гоффман схиляється до думки, що гібридні війни можуть вести не лише держави, а й різноманітні недержавні учасники. Мультимодальні заходи проводять окремі підрозділи, або навіть той самий підрозділ, але, як правило, оперативно і тактично координований у загальній площині для досягнення синергетичного ефекту у фізичному та психологічному вимірах конфлікту. Ефекти можуть бути отримані на всіх рівнях війни.

Американський військовий теоретик автор книги "The Accidental Guerilla" Д. Кілкаллен визначив гібридну війну так: “це краще визначення сучасних конфліктів, у яких скомбіновано партизанську та громадянську війни, а також заколот і тероризм" [20].

У дослідженні гібридної війни у контексті асиметричного світоустрою О. Полтораков [21] наводить визначення надане колишнім радником НАТО генерал-майором Ф. Ван Каппеном: “гібридна війна - це змішування класичного типу війни з використанням нерегулярних військових формувань.
Держава, яка веде гібридну війну, укладає угоду $з$ недержавними виконавцями бойовиками, групами місцевого населення, організаціями, зв'язок із якими повністю заперечує".

На думку науковців Національного інституту стратегічних досліджень початок агресії з боку Російської Федерації щодо України у 2014 році став вихідною точкою для осмислення гібридної війни як окремого феномену.

Так, начальник генерального штабу збройних сил РФ В. Герасимов у 2013 році напередодні агресії РФ проти України під час доповіді на тему: “Основні тенденції розвитку форм та способів застосування збройних сил, актуальні завдання воєнної науки щодо їх вдосконалення" наголосив на зростанні ролі невоєнних способів у досягненні політичних і стратегічних цілей, а також зазначив: “Акцент методів протиборства зміщується у бік широкого застосування політичних, економічних, інформаційних, гуманітарних та інших невоєнних заходів, реалізованих із залученням протестного потенціалу населення. Усе це доповнюється прихованими військовими заходами, у тому числі за допомогою реалізації заходів інформаційного протиборства та дії сил спеціальних операцій" [22]. Отже, головною думкою зазначеної доповіді стало виокремлення ролі невоєнних заходів під час вирішення міждержавних конфліктів (Рис. 1). 


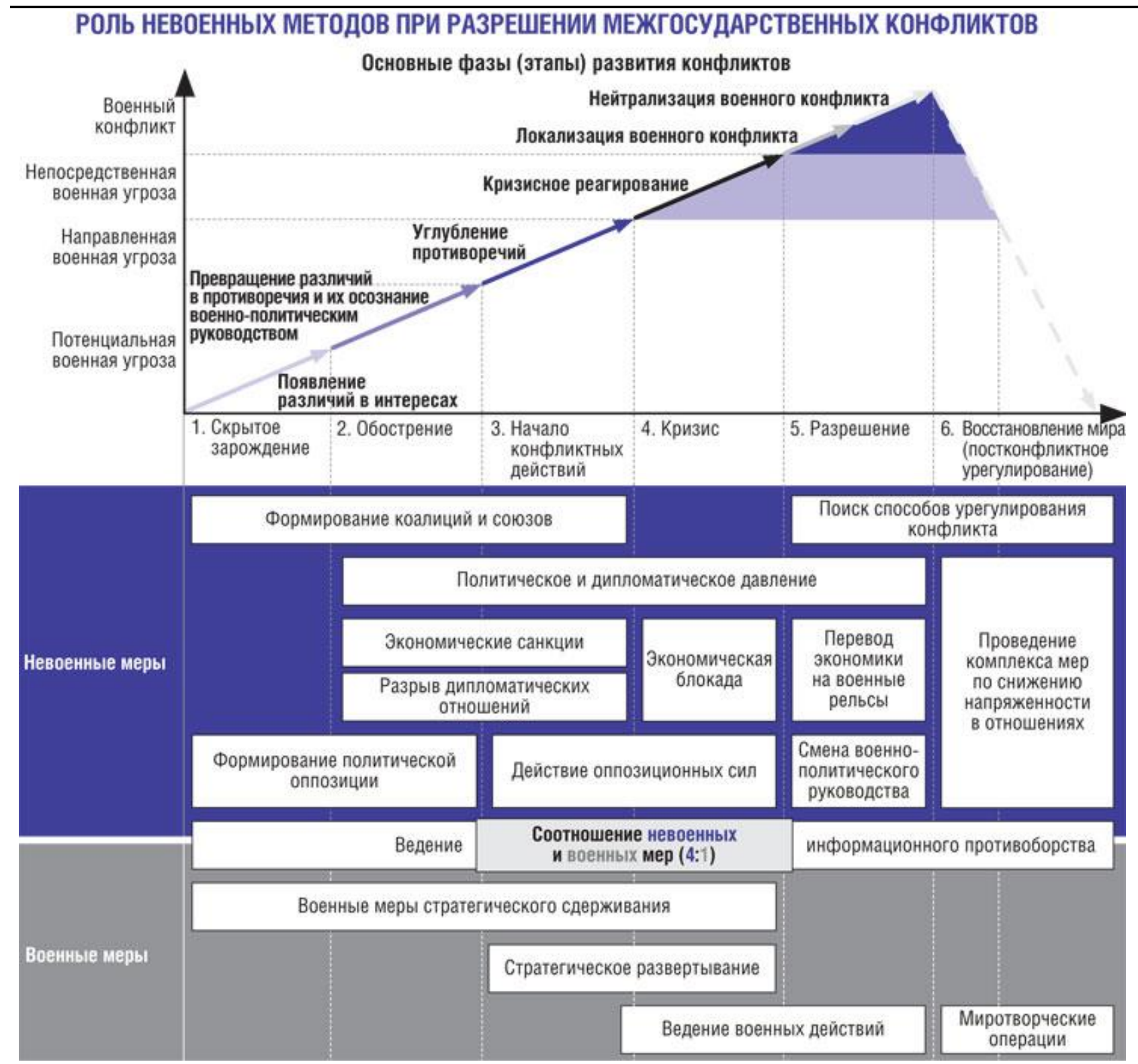

Рис. 1 - Роль невійськових методів під час вирішення міждержавних конфліктів за В. Герасимовим (наведено в оригіналі)

3 огляду на викладене можна ведення. Це підтверджено не лише думками констатувати, що гібридна війна об'єднує більшості вітчизнянихта іноземних науковців, широке коло методів та інструментів ії а й наявністю історичнихприкладів (Табл. 2).

\section{Таблиця. 2 - Збройні конфлікти, у яких виявлено ознаки гібридної війни}

\begin{tabular}{|c|l|l|}
\hline \multicolumn{1}{|c|}{ Рік } & \multicolumn{1}{|c|}{$\begin{array}{c}\text { Найменування збройного } \\
\text { конфлікту }\end{array}$} & \multicolumn{1}{|c|}{ Особливість } \\
\hline 431-404 до н.е. & Пелопоннеська війна & $\begin{array}{l}\text { Підбурювання до повстання місцевого } \\
\text { населення }\end{array}$ \\
\hline 1939 & Окупація Польщі Німеччиною & $\begin{array}{l}\text { Перевдягнутими в польську форму } \\
\text { німецькими військовими вбивства своїх } \\
\text { співвітизників, що стало приводом збройної } \\
\text { агресії }\end{array}$ \\
\hline $1946-1989$ & Холодна війна & $\begin{array}{l}\text { Ідеологічна боротьба, війна у міжнародному } \\
\text { та правовому полі, конфронтація у світовій } \\
\text { політиці; }\end{array}$ \\
\hline
\end{tabular}


ISSN 2522-9842 Journal of Scientific Papers "Social Development and Security", Vol. 11, No. 1, - 2021

\begin{tabular}{|c|c|c|}
\hline Рік & $\begin{array}{c}\text { Найменування збройного } \\
\text { конфлікту }\end{array}$ & Особливість \\
\hline 1991 & Карабаський конфлікт & $\begin{array}{l}\text { Широке застосування НЗФ та регулярних } \\
\text { військ під виглядом місцевого населення, } \\
\text { невизнання присутності регулярних збройних } \\
\text { сил }\end{array}$ \\
\hline 1992 & Придністровський конфлікт & $\begin{array}{l}\text { Широке застосування НЗФ, ведення } \\
\text { ідеологічної боротьби }\end{array}$ \\
\hline 2006 & Лівано-Ізраїльський конфлікт & $\begin{array}{l}\text { Демонстрування неурядовою організацією } \\
\text { здатності знаходити уразливі місця збройних } \\
\text { сил та розробляти відповідні контрзаходи }\end{array}$ \\
\hline 2008 & Російсько-грузинська війна & $\begin{array}{l}\text { Застосування інформаційних, економічних, } \\
\text { кібернетичних інструментів }\end{array}$ \\
\hline $\begin{array}{l}32012 \text { року до } \\
\text { цього часу }\end{array}$ & Громадянська війна в Сирії & $\begin{array}{l}\text { Ведення прихованої війни між сунітськими } \\
\text { державами (Саудівською Аравією, } \\
\text { Туреччиною і Катаром) та Іраном і Хезболлою }\end{array}$ \\
\hline 2014 & $\begin{array}{l}\text { Збройна агресія РФ проти } \\
\text { України }\end{array}$ & $\begin{array}{l}\text { Широке застосування НЗФ та регулярних } \\
\text { військ під виглядом місцевого населення; } \\
\text { широке застосування економічних, } \\
\text { політичних, інформаційних інструментів }\end{array}$ \\
\hline
\end{tabular}

Також ознаки гібридної війни можна простежити під час таких збройних конфліктів: римсько-германських війн, придушення англійцями Ірландії в 1594-1603 рр.; Американської революції; піренейських війн; протипартизанських дій у ході громадянської війни у США, Франкопрусської війни (1870-1871), Японськокитайської війни (1937-1945), Корейської війни (1950-1953), В'єтнамської війни.

щодо регламентації терміна у нормативно-правових документах, то В. Петрик та Ю. Канарський у своєму дослідженні вказують на відсутність визначення терміна "гібридна війна" у міжнародних нормативно-правових документах [23].

У концепції “NATO”s Bi-Strategic Command Capstone Concept" (2010) "гібридні загрози" визначено як загрози, які створено противником, здатним одночасно й адаптовано використовувати традиційні i нетрадиційні засоби для досягнення власних цілей [24].

Після початку агресії Російської Федерації у 2014 році активізувалася тенденція до регламентованості проблематики гібридної війни у наукових джерелах, а також імплементації її у нормативно-правові документи. Так, у 2014 році у ході проведення саміту країн - членів НАТО в м. Уельс вперше на вищому офіційному рівні проведено конструктивну дискусію щодо необхідності підготовки НАТО до нових викликів, а саме участі у війнах нового типу - гібридних [25].

Міжнародний інститут стратегічних досліджень (IISS) з 1959 року видає аналітичну збірку "Military Balance" в якій фахівці оцінюють військовий потенціал та оборонну економіку 171 країни. У збірці за 2015 рік гібридну війну визначено як: "використання воєнних і невоєнних інструментів в інтегрованій кампанії, скерованій на досягнення раптовості, захоплення ініціативи й отримання психологічних переваг із використанням дипломатичних можливостей; масштабні і стрімкі інформаційні, електронні і кібероперації; прикриття та приховування військових і розвідувальних дій у поєднанні 3 економічним тиском" [26-27].

Так, 11 квітня 2017 року засновано Європейський центр 3 протидії гібридним загрозам (European Centre of Excellence for Countering Hybrid Threats), a came: кібератакам, пропаганді та дезінформації. Центр організували у Гельсінкі такі країни: США, Велика Британія, Франція, Німеччина, 
Швеція, Польща, Фінляндія, Латвія і Литва.

У 2018 році Парламентська асамблея Ради Європи (ПАРЄ) ухвалила резолюцію про протидію гібридній війні. У ній явищами гібридної війни названо кібератаки, фейкові новини, масову дезінформацію, а також наголошено, що гібридна війна спрямована на дестабілізацію досягненні цілей визначених суспільством.

Зазначені заходи $€$ безумовним прикладом стурбованості західних та міжнародних партнерів наявністю гібридних загроз та спрямовані на розроблення відповідних зусиль для протидії їм.

На національному рівні у Стратегії національної безпеки України визначено, що для відновлення свого впливу в Україні Російська Федерація, продовжуючи гібридну війну, системно застосовує політичні, економічні, інформаційно-психологічні, кібер- і воєнні засоби [28].

Проаналізуємо підходи до визначення змісту і природи “гібридної війни", відображені у публікаціях вітчизняних науковців.

Так, В. П. Горбулін у колективній монографії “Світова гібридна війна: український фронт” зазначає: “Гібридну війну у загальному вигляді розуміють як воєнні дії, що поєднують міліарні, квазімілітарні, дипломатичні, інформаційні, економічні та інші засоби для досягнення стратегічних політичних цілей". Також науковець наголошує що "гібридні загрози - це загрози, створені противником, здатним до одночасного застосування звичайних i нетрадиційних засобів в адаптивний спосіб для досягнення своїх цілей" [29].

У своєму дослідженні 3. Коваль схиляється думки, що гібридна війна - це поняття, вужче за асиметричну війну, і $€$ основним інструментом асиметричної війни [30], поєднуючи широкий діапазон гібридних загроз: кібервійну, асиметричні конфлікти низької ефективності, глобальний тероризм, піратство, незаконну міграцію, корупцію, етнічні і релігійні конфлікти, безпеку ресурсів, демографічні виклики, транснаціональна організовану злочинність, проблеми глобалізації, поширення зброї масового знищення.

Під час дослідження феномену гібридної війни у соціологічній площині І. Рущенко вказує на широту його висвітлення у наукових джерелах та наявність й інших, на його думку, синонімічних назв, що у своїй сукупності становлять методи гібридної війни: кольорові революції, непрямі дії, латентні дії, громадянська війна, війни керованого хаосу, нелінійні війни, змішані, комбіновані війни, повстанські дії, мережеві дії, мережевоцентричні війни, неконвенційні війни, нестандартні війни, кримінальнотерористичні війни.

Дослідники 3. Коваль, І. Рущенко та інші у ході досліджень широко застосовують поняття “гібридна війна” взаємопов'язано із поняттям "асиметрична війна". Інститут стратегічних досліджень США визначає асиметрію, у військовій сфері та сфері національної безпеки як “вміння діяти, організовувати свою діяльність та мислити відмінним від опонентів чином з метою максимізації власних переваг та використання уразливих місць опонента, захоплення ініціативи чи забезпечення простору для маневрування" [31].

Досліджуючи питання гібридної війни в економічному вимірі, Г. Жекало вказує на наявність поняття "війни у мирний час", що характеризується використанням як регулярних, так і нерегулярних збройних формувань стосовно до іншої держави 3 одночасною пролонгацією дії дипломатичних відносин та поєднанням політичних, економічних, інформаційних інструментів без оголошення війни одна одній [32].

На думку О. Золотаря сутність гібридної війни розкривається через "синергію різних вимірів протистояння - інформаційного, політичного, економічного, соціального, гуманітарного, воєнного. При цьому глобальною метою гібридної війни $\epsilon$ закріплення частини стратегічно важливих ресурсів країни-жертви за агресором" [33].

Наприклад, Є. Магда підтримує концепцію визначення гібридної війни як агресії однією держави щодо іншої за допомогою широкого 
використання політичних, економічних та інформаційних інструментів [34].

Досліджуючи феномен гібридної війни у інформаційній сфері, Г. Почепцов наголошує на розумінні їі не тільки в інформаційному полі, а й в усіх інших галузях, пов'язаних із людською діяльністю [35].

Одним з перших українських дослідників, що сформулював визначення гібридна війни став М. Требін: “Гібридна війна - це комбінація з партизанської і громадянської війни, заколоту і тероризму, головними дійовими особами яких $\epsilon$ нерегулярні військові формування, бойовики, кримінальні банди, міжнародні терористичні мережі, спецслужби іноземних держав, приватні військові компанії, військові контингенти міжнародних організацій" [36].

Також М. Требін досліджуючи проблематику гібридної війни в умовах українських реалій, дійшов висновку, про наявність трьох їі складових: гібридної війни:

поєднання конвенційних і неконвенційних бойових дій;

широкого застосування незаконних (іррегулярних) збройних формувань;

ведення інформаційної боротьби (протидії) [37].

Досліджуючи збройну агресію Російської Федерації проти України, В. Петрик та Ю. Канарський розуміють гібридну війну як війну, що поєднує широкий спектр способів її ведення для досягнення визначених цілей без оголошення війни [38].

Проводячи дослідження в інформацій-ному полі, А. Шиян, А. Поплавський, Л. Нікіфорова, І. Заступ, дійшли висновку, що метою гібридної війни є “дестабілізація соціального та економічного стану у країні, що призводить до зменшення рівня національної безпеки" [39].

У дослідженні Д. Сидоренка понятя гібридної війни визначено як “конфлікт між державами або між державою і недержавним утворенням, в якому один суб'єкт чинить щодо іншого суб'єкта пряму агресію з прихованим застосуванням своїх збройних сил або опосередковано через інших суб'єктів, комплексно застосовуючи політичні, економічні, інформаційні та інших невійськові заходи, а також терористичні, диверсійні і кримінальні технології для позбавлення сторони-противника фактичного суверенітету, при цьому сторони такого конфлікту перебувають у стані “гібридного миру" (тобто, юридично це не війна, але фактично це не мир)" [40].

На нашу думку, ключовою тезою зазначеного $\epsilon$ вказання на можливість гібридного конфлікту не лише між певними країнами, а й між країною та недержавним утворенням.

У дослідженні Н. Карпчука гібридну війну визначено як "сукупність заздалегідь підготовлених та оперативно реалізованих військових, дипломатичних, економічних, інформаційних дій, спрямованих на досягнення стратегічних цілей" [41].

Науковці В. Телелим, Д. Музиченко та Ю. Пунда у дослідженні проблематики планування під час виконання бойових завдань у гібридній війні розглядають сутність предметного понятя у двох площинах: загальній та військовій. У загальній площині науковці гібридну війну визначають як “крайній ступінь загострення протиріч між державами, які вирішуються не тільки військовими методами протиборства, а й широким застосуванням заходів, форм і способів економічної та інформаційної війни”, у військовій сфері - як "зміщення акцентів у бік уникнення прямих зіткнень збройних сил конфліктуючих держав та досягнення цілей війни діями повстанців, добровольців, ополченців, та мінімізація такими діями власних людських втрат" [42].

у дослідженні досвіду отриманого Повітряними Силами Збройних Сил України протягом збройної агресії з боку Російської Федерації, А. Алімпієв та Г. Пєвцов визначають гібридну війну як комплекс економічних, фінансових, матеріальнотехнічних, інформаційно-пропагандистських та військових заходів, які веде Російська Федерація проти України [43].

Досліджуючи питання технології гібридної війні Ю. Радковець констатує, що такий термін застосовують у ситуаціях, коли необхідно охарактеризувати гнучку і складну динаміку бойового простору, що у свою 
чергу, передбачає нескладну адаптацію та гнучку реакцію [44].

У дослідженні проблематики гібридної війни проти України, В. Ліпкан зазначає, що “суть гібридної війни полягає в тому, щоб одна домінантна група управління (альфагрупа, незалежно від того держава це чи могутня транснаціональна корпорація, синдикат) підкорила і створила необхідні та достатні умови для підкорення іншої соціальної групи (соціальної системи, громадянського суспільства, держави тощо), при цьому не встановлюючи повного та тотального контролю над суверенітетом і територією, іншими важливими, але не життєво необхідними атрибутами, що супроводжується також капітуляцією збройних сил" [45].

На думку А. Дацюка, О. Пошедіна, Л. Шипілової гібридна війна $\epsilon$ “формою конфлікту, для якого характерне одночасне використання політичних, економічних, інформаційно-психологічних методів силового впливу на противника в поєднанні 3 військовими заходами у вигляді проведення розвідувально-диверсійних операцій силами спецпідрозділів, формування, підтримки і координації дій незаконних воєнізованих формувань сепаратистів, терористичних угруповань тощо" [46].

Науковці Національної академії Служби безпеки України О. Акульшин, О. Заруба, Л. Компанцева, С. Кудінов, Н. Слухай, О. Снитко. сформулювали таке визначення: "як гібридну війну розумітимемо гетерогенне поєднання та застосування без офіційного оголошення війни класичних та асиметричних стратегій, тактик, засобів прихованого глобального впливу однієї держави на іншу з метою політичної мотивації, інформаційного впливу, дестабілізації соціально-політичної та економічної ситуації, негативного втручання у функціонування внутрішньої інфраструктури, деморалізації громадянського суспільства, блокування та дискредитації політичних ініціатив, руйнування цілісності системи державного управління шляхом порушення внутрішньої стратегічної взаємодії між складовими сектору безпеки і оборони, органами державної влади, місцевого самоврядування, установами, організаціями, закладами, розпалювання міжетнічної, міжконфесійної, соціальної ворожнечі й ненависті, сепаратизму і тероризму та, як наслідок, порушення територіальної цілісності та суверенітету" [47].

На підставі аналіз основних вітчизняних досліджень наявних у широкому доступі складено таблицю (Табл. 3), В якій узагальнено сучасний стан розуміння терміна гібридна війна та природи її ведення.

Особливості розуміння і тлумачення терміна “гібридна війна" проаналізовано за чотирьома складовими:

1) явище, процес (категорія для визначення особливостей і змісту певного предмету, явища, або процесу);

2) дійові особи (коло учасників які беруть участь у визначеному процесі);

3) інструменти/складові (засіб, спосіб для досягнення визначеної мети);

4) мета (прагнення задля яких чинять вплив визначеними інструментами і методами).

Щодо складової № 1. Аналіз підходів до визначення науковцями явища "гібридної війни" показав, що це агресія (з приховуванням своїх збройних сил або опосередковано через інших суб'єктів), дії (воєнні, мережеві), війна (нелінійна, змішана, комбінована, мережевоцентрична, не конвенційна, нестандартна, кримінально-терористична, комбінація 3 партизанської (повстантської) і громадянської війн), конфлікт (асиметричний, низької ефективності), синергія різних вимірів протистояння, заколоту і тероризму та крайній ступінь загострення протиріч у поєднанні класичних й асиметричних стратегій, тактик, засобів прихованого глобального впливу.

Щодо складової № 2. Аналіз підходів до визначення науковцями дійових осіб (учасників) "гібридної війни" показав, що це можуть бути держави, недержавні утворювання, транснаціональні корпорації, синдикати, соціальними системи, громадянські суспільства, незаконні військові формування, кримінальні банди, міжнародні терористичні мережі, спецслужби іноземних держав, 
приватні військові компанії, військові контингенти міжнародних організацій.

Щодо складової № 3. Аналіз підходів до визначення науковцями інструментів / методів елементів "гібридної війни” показав, що такими можуть бути: міліарні, квазімілітарні (розвідувально-диверсійні операції силами спецпідрозділів, використання повстанців, добровольців, ополченців, терористичні та кримінальні технології), політичні, економічні, дипломатичні, інформаційно-пропагандистські, інформаційно-психологічні, соціальні, гуманітарні та матеріально-технічні інструменти (методи).

Щодо складової № 4. Аналіз підходів до визначення науковцями мети гібридної війни показав, що сторони можуть прагнути:

досягнути стратегічних політичних цілей, загальних цілей війни, досягнення визначених цілей без оголошення війни;

дестабілізувати соціально-політичну та економічну ситуацію, негативно втрутитися у функціонування внутрішньої інфраструктури, деморалізувати громадянське суспільство, блокувати і дискредитувати політичні ініціативи, руйнувати цілісність системи державного управління;

порушувати внутрішню стратегічну взаємодію між складовими сектору безпеки й оборони, органами державної влади, місцевого самоврядування, установами, організаціями, закладами, розпалювати міжетнічну, міжконфесійну, соціальну ворожнечу й ненависть, сепаратизм i тероризм, порушувати територіальну цілісність та суверенітет;

закріпити частину стратегічно важливих ресурсів країни-жертви за агресором;

позбавити (частково) сторону-противника фактичного суверенітету;

не встановлювати повний та тотальний контроль за територією.

Проведений аналіз за визначеними чотирьома складовими дає змогу сформулювати універсальне розуміння понятяя “гібридна війна", де “гібридна війна": це агресія (з приховуванням своїх збройних сил або опосередковано через інших суб'єктів), дії (воєнні, мережеві), війна (нелінійна, змішана, комбінована, мережево-центрична, неконвенційна, нестандартна, кримінальнотерористична, комбінація 3 партизанської (повстанської) і громадянської війн), конфлікт (асиметричний, низької ефективності), синергія різних вимірів протистояння, заколоту i тероризму та крайній ступінь загострення протиріч у поєднанні класичних й асиметричних стратегій, тактик, засобів прихованого глобального впливу що здійснюється між державами, недержавними утвореннями, транснаціональними корпораціями, синдикатами, соціальними системами, громадянськими суспільствами, незаконними військовими формуваннями, кримінальними бандами, міжнародними терористичними мережами, спецслужбами іноземних держав, приватними військовими компаніями, військовими контингентами міжнародних організацій із широким застосуванням міліарних, квазімілітарних (розвідувально-диверсійних операцій силами спецпідрозділів, використання повстанців, добровольців, ополченців, терористичних та кримінальних технологій), політичних, економічних, дипломатичних, інформаційнопропагандистських, інформаційнопсихологічних, соціальних, гуманітарних та матеріально-технічних інструментів (методів) для досягнення стратегічних політичних цілей, загальних цілей війни, у тому числі без оголошення війни, для дестабілізації соціально-політичної та економічної ситуації, негативного втручання у функціонування внутрішньої інфраструктури, деморалізації громадянського суспільства, блокування та дискредитації політичних ініціатив, руйнування цілісності системи державного управління, порушення внутрішньої стратегічної взаємодії між складовими сектору безпеки й оборони, органами державної влади, місцевого самоврядування, установами, організаціями, закладами, розпалювання міжетнічної, міжконфесійної, соціальної ворожнечі й ненависті, сепаратизму i тероризму, порушення територіальної цілісності та суверенітету, закріплення частини стратегічно важливих ресурсів країни-жертви за 
агресором; позбавлення (часткового) сторонипротивника фактичного суверенітету за умови необов'язкового встановлення повного i тотального контролю за територією, при цьому сторони такого конфлікту перебувають у стані "гібридного миру"/неоголошеної війни.

Зазначимо, що запропонована площина понятяя $\epsilon$ досить широкою, що у разі потреби може бути звужена для загального визначення гібридної війни, а саме: “це вид агресії, дій, війни, конфлікту, синергія різних вимірів протистояння, заколоту і тероризму, крайній ступінь загострення протиріч у поєднанні класичних та асиметричних стратегій, тактик, засобів прихованого глобального впливу між державами, недержавними утвореннями, транснаціональними

синдикатами, соціальними системами, громадянськими суспільствами, незаконними військовими формуваннями, кримінальними бандами, міжнародними терористичними мережами, спецслужбами іноземних держав, приватними військовими компаніями, військовими контингентами міжнародних організацій із широким застосуванням міліарних, квазімілітарних, політичних, економічних, дипломатичних, інформаційних, соціальних, гуманітарних та матеріальнотехнічних інструментів (методів) для досягнення стратегічних військових, політичних та економічних цілей за умови необов' язкового встановлення повного і тотального контролю над територією, при цьому сторони такого конфлікту перебувають у стані “гібридного миру" (неоголошеної війни).

Разом з тим, сформульоване визначення у широкому сенсі є мультидисциплінарним, що необхідно для окреслення перспектив подальших вивчення у предметній сфері, а саме під час дослідження широкого кола різносторонніх аспектів феномену гібридної війни.

3 огляду на викладене важко не погодитися 3 науковцями Національного інституту стратегічних досліджень щодо доцільності формулювання терміна "гібридна війна" як “парасолькового" (umbrella term) через різнорідність об'єднуваних елементів, непотрібність охоплення терміном усіх випадків ведення гібридної війни, натомість ідентифікації спільних характеристик, принципів та ознак у розумінні предметного явища [7, с.22].

Зазначимо, що думка вітчизняних учених щодо розуміння предметного терміна, безумовно, сформувалася 3 урахуванням двох факторів:

нетипової агресії РФ проти України;

поглядів викладених у працях Ф. Гофмана, Г. Іссерсона, Є. Месснера, Т. Гюбера, Р. Волкера, В. Немета, Д. Маккуена, В. Герасимова та інших.

3 огляду на викладене у порівняльну таблицю погляди на явище гібридної війни зазначених науковців та військових діячів не були внесені.

Отже, результати проведеного аналізу дали змогу сформулювати універсальне визначення, ідентифіковане з урахуванням останніх подій в України В контексті неоголошеної війни з боку РФ. Це у свою чергу, дасть змогу визначити перспективи подальших досліджень у сфері протидії гібридним загрозам з боку РФ, адже розуміння природи гібридної війни $\epsilon$ вихідною точкою для ідентифікації усіх інструментів та методів гібридної війни і наслідків від їх застосування.

\section{Висновки}

Таким чином, думку вітчизняних учених щодо розуміння терміна "гібридна війна" сформовано переважно на підставі прецеденту неоголошеної агресії РФ проти України та поглядів викладених у працях Ф. Гофмана, Г. Іссерсона, $€$. Месснера, Т. Гюбера, Р. Волкера, В. Немета, Д. Маккуена, В. Герасимова та ін.
Тенденція до актуалізації гібридних засобів ведення війни i, як наслідок сучасне доповнення формулювання війни ознакою гібридності підтвердженні проведеним аналізом історичних та сучасних подій, що відбуваються у світі під час вирішення протиріч із застосуванням широкого спектру військових, економічних, соціальних, 
інформаційних та інших інструментів. Дослідження проблематики гібридних викликів та загроз, безумовно мають бути враховані у процесі оборонного планування.

Станом на сьогодні регламентацію явища гібридної війни у вітчизняних та іноземних нормативно-правових документах висвітлено не достатньо, тому це $\epsilon$ одним із перспективних напрямів, що потребує комплексного дослідження.

Результати наукового дослідження викладені у цій статті, $є$ вихідною точкою для широкого дослідження економічних та інших інструментів ведення гібридної війни.

\section{Список використаних джерел}

1. Carl von Clausewitz, On War, Michael Howard and Peter Parent, eds. and trans., Princeton, NJ: Princeton University Press, 1976, p. 77. See also Christopher Daase, "Clausewitz and Small Wars," in Hew Strachan and Andreas HerbergRothe, eds., Clausewitz in the Twenty-First Century, New York, NY: Oxford University Press, 2007

2. Требін М. П. Гібридна війна як нова українська реальність. Український соціум. 2014. №3 (50). С. 113-127.

3. Hoffman, F.G. Conflicts in the 21st Century: The Rise of Hybrid Wars / Potomac Institute for Policy Studies. - Arlington, VA, 2007. - P. 14.

4. "The Black Swan: The Impact of the Highly Improbable", The New York Times, by Nassim Nicholas Taleb, April 22, 2007.

5. Словник української мови. Академічний тлумачний словник (1970-1980). URL: http://sum.in.ua/s/zmishanyj.

6. Годованик Є. В., Русаневич А. Т. Міжнародноправові проблеми "гібридних" збройних конфліктів у сучасному світі. Вісник маріупольського державного університету, серія: право. 2017. №. 14. С. 56-68.

7. Світова гібридна війна: український фронт : монографія / за заг. Ред. В. П. Горбуліна. Харків : Фоліо, 2017. - 496 с.

8. Walker, R. G. SPEC FI: the United States Marine Corps and Special Operations. Naval Postgraduate School. - Monterey, California, December 1998.

9. Huber, T. M. Compound Warfare: A Conceptual Framework //. Compound Warfare: That Fatal Knot/ Thomas M. Huber, ed. : US Army Command and General Staff College Press. Fort Leavenworth, KS, 2002. P. 2.

10. Hoffman, F. G. Conflicts in the 21st Century: The Rise of Hybrid Wars / Potomac Institute for
Policy Studies. - Arlington, VA, 2007. - P. 14.

11. Nemeth, W. J. USMC, Future War and Chechnya: A Case for Hybrid Warfare / Naval Postgraduate School. - Monterrey, CA, June 2002.

12. Hoffman, F.G. Retrospectives on the Future Security Environment, statement before the Subcommittee on Intelligence and Emerging Threats and Capabilities / House Armed Services Committee. - U.S. House of Representatives, February 13, 2012. - P. 3.

13. Курбан О. В. Сучасні інформаційні війни в мережевому он-лайн просторі: навч. посіб. Київ: ВІКНУ, 2016. 286 с. URL: http://www.mil.univ.kiev.ua/files/222_10442 84240.pdf.

14. McCuen John J. Hybrid Wars. Military Review. 2008 . № 3(4). URL: http://www.au.af.mil/au/awc/awcgate/milrev iew/mccuen08marapr.pdf

15. Полтораков О. Гібридна війна в контексті асиметричного світоустрою. Збірник наукових праць "Гілея": Науковий вісник. 2016. № 100, C. 258-259.

16. Герасимов В. Ценность науки в предвидении. Независимое военное обозрение. 2013. № 8(476).

17. Reeves S. R. The New Griffin of War: Hybrid International Armed Conflicts / S. R. Reeves, R. E. Barnsby // Harvard International Review. Mode of access: https://www.questia.com/library /journal/1G1-316203914/the-new-griffin-ofwar-hybrid-international-armed. - Title from the screen.

18. Fleming B. P. The Hybrid Threat Concept: Contemporary War, Military Planning and the Advent of Unrestricted Operational Art : Monograph / B. P. Fleming. - School of Advanced Military Studies United States Army 
Command and General Staff College Fort Leavenworth, Kansas. - AY, 2011. - 85 p.

19. Шевчук В. В., Пунда Ю. В. Міграційна криза як складова гібридної війни. Information and analytical activities in the field of security and defense. 2020. № 2(38). C. 95-100.

20. Kilcullen D. Out of the Mountains: The coming age of the urban Guerrilla / D. Kilcullen. Oxford. University Press.

21. Полтораков О. Гібридна війна в контексті асиметричного світоустрою. Збірник наукових праць "Гілея": Науковий вісник. 2016. № 100, C. 258-259.

22. Gerasimov V. The Value of Science Is in the Foresight // Military Review. - 2016. January-February. - P. 23-29. (en).

23. Петрик К., Канарський Ю. Методи гібридної війни Росії проти України. Напрями протидії. Information technology and security. 2015. № 3/1 (4). C. 30-37.

24. NATO's Bi-Strategic Command Capstone Concept, 5000 FXX/0100/TT-0651/SER: NU0040 Dated 25 August 2010.

25. Коваль 3. Інформаційно-психологічна стійкість як стрижень стратегії протидії асиметричним (гібридним) війна. Актуальні проблеми державного управління. 2016. № 2(66). C. 59-63.

26. Феденко О. В. Гібридна війна в Україні як фактор сучасної холодної війни для Росії. Молодий вчений. 2017. № 9 (49). С. 119-125.

27. The Military Balance 2015. NY: The International Institute for strategic studies, 2015. - $501 \mathrm{p}$.

28. Про рішення Ради національної безпеки і оборони України від 14 вересня 2020 року “Про Стратегію національної безпеки України": Указ Президента України від 14.09.2020 №392/2020.

29. Світова гібридна війна: український фронт : монографія / за заг. ред. В. П. Горбуліна - К.: НІСД, 2017. - 496 c.

30. Коваль 3. Інформаційно-психологічна стійкість як стрижень стратегії протидії асиметричним (гібридним) війнам. Актуальні проблеми державного управління. 2016. № 2(66). С. 59-63.

31. Steven Metz, Douglas Jonson. P.5 //
Asymmetry and US Military Strategy: Definition Background and Strategic Concepts. Strategic Studies Institute, 2001.

32. Жекало Г. І. Гібридна війна РФ проти України: економічний вимір. Збірник наукових праць "Гілея: науковий вісник". 2017. № 145. С. 47-51.

33. Золотар О. О. Особливості інформаційної безпеки людини в умовах гібридної війни. Інформачія і право. 2017. № 3(22). С. 124131.

34. Магда Є. В. Гібридна війна : вижити і перемогти / Є. В. Магда. - Х. : Віват, 2015. $304 \mathrm{c}$.

35. Почепцов Г. Гібридна війна : Інформаційна складова.

URL: http://osvita.mediasapiens.ua/trends/141197 8127/gibridna_viyna_informatsiyna_skladova

36. Требін М. Феномен “гібридної війни”. Гілея. 2014. Випуск 87 (8). С. 366-371.

37. Требін М. П. Гібридна війна як нова українська реальність. Український сочіум. 2014. № 3. С. 113-127.

38. Петрик К., Канарський Ю. Методи гібридної війни Росії проти України. Напрями протидії. Information technology and security. 2015. № 3/1 (4). C. 30-37.

39. Шиян А. А, Поплавський А. В., Нікіфорова Л. О., Заступ І. В. Модель розрахунку рівня напруги у суспільстві для прийнятяя ефективних рішень із захисту національної безпеки. Інформатика та математичні методи в моделюванні. 2018. № 8(4). С. 345343.

40. Сидоренко Д. А. Гібридна війна як сучасний спосіб ведення війни. Молодий вчений. 2018. № 11 (63). С. 920-923.

41. Карпчук Н. Медіа як невоєнний метод впливу в гібридній війні. Суспільні комунікації. 2018. №2(4). С. 41-49.

42. Телелим В. М., Музиченко Д. П., Пунда Ю. В. Планування сил для виконання бойових завдань у “гібридній війні". Наука і оборона. 2014. № 3. С. 30-35.

43. Алімпієв А. М., Пєвцов Г. В. Особливості гібридної війни РФ проти України. Досвід, що отриманий Повітряними Силами Збройних Сил України. Наука i техніка 
Повітряних Сил Збройних Сил України. 2017. № 2(27). С. 19-25.

44. Радковець Ю.І.Ознаки технологій “гібридної війни" в агресивних діях Росії проти України. Наука і оборона. 2014. № 3. С. 36-42.

45. Ліпкан В. А. Сутність гібридної війни проти України. URL: http://goal-int.org/sutnistgibridnoi-vijni-proti-ukraini/.

46. Дацюк А., Пошедін О., Шипілова Л. Структурно-функціональний безпекових аспектів політики європейської інтеграції в умовах протидії російській агресії в гібридній війні проти України. Теорія $i$ практика публічного управління. Збірник наукових праць НАДУ. 2019. № 1/2019. С. 6168.

47. Гібридна війна: технології сугестії та контрсугестії: монографія / О. Акульшин, О. Заруба, Л. Компанцева, С. Кудінов, Н. Слухай, О. Снитко. Київ: Національна академія СБУ, 2018. 236 с.

\title{
Анализ и систематизация подходов к пониманию понятия “гибридной войны”
}

\author{
Анатолий Лойшин ${ }^{1}$ А; Иван Ткач 2 А; Николай Ткач ${ }^{3}$ А; Виталий Шевчук 4 А \\ ${ }^{1}$ Corresponding author: доктор философии, старший преподаватель кафедры экономики и финансового обеспечения, \\ e-mail: aloishyn@gmail.com, ORCID: 0000-0003-2769-9336 \\ 2 Доктор экономических наук, профессор, Начальник центра оборонного менеджмента, e-mail: tkachivan9@gmail.com, \\ ORCID: 0000-0001-5547-6303 \\ ${ }^{3}$ кандидат технических наук, начальник кафедры оборонного менеджмента, e-mail: nyck1985@ukr.net, ORCID: 0000-0002-8832-1268 \\ ${ }^{4}$ кандидат военных наук, начальник научно-исследовательской лаборатории проблем военной безопасности государства, \\ e-mail: shevchuksnbo@ukr.net, ORCID: 0000-0002-8532-739x \\ А Национальный университет обороны Украины имени Ивана Черняховского, пр-кт Воздухофлотский, 28, г. Киев, 03049, Украина
}

\begin{abstract}
Аннотация
В статье обобщены аргументы и контраргументы в научной дискуссии по вопросу феномена гибридной войны с учетом втягивания Украины Российской Федерацией в состояние необъявленной гибридной войны.
\end{abstract}

Основными целями исследования является анализ и систематизация подходов к пониманию природы гибридной войны отечественными и иностранными учеными, обобщения ее ключевых особенностей и формулировки синтезированного определения с учетом продолжающейся агрессии против Украины.

На основании систематизации широкого круга научных трудов и подходов к решению проблемы исследования природы гибридной войны выявлена тенденция к росту внимания среди ученых к ее исследованию.

Актуальность решения этой научной проблемы в украинском измерении заключается в непосредственно вовлечении Украины в плоскость необъявленной войны.

Проблематику гибридной войны в статье исследовано в такой логической последовательности: ретроспективно проанализированы развитие, формирование и идентификацию содержания терминов "гибридная война", "гибридные средства ведения войны"; үстановлена взаимосвязь между гибридной войной, широким кругом ее методов и инструментов; выделены признаки гибридной войны в ряде войн и конфликтов; проанализированы тенденции к регламентации проблематики гибридной войны не только в научных источниках, но и в нормативно-правовых документах; проанализированы подходы к определению содержания и природы гибридной войны отражены в публикациях отечественных ученых, в соответствии с чем сформулировано универсальное толкование термина, и подтверждено мнение о его “зонтичное" значения. Методическим инструментарием исследования стали методы анализа, синтеза и системного подхода, графиком частично охвачено исторические события со времен Пелопоннесской войны до современности.

Объектом исследования избран войну во всех ее проявлениях, поскольку именно 
гибридная война является производной от обычной конвенциональной войны.

В статье даны результаты эмпирического анализа подходов к пониманию природы гибридной войны, показывают, необходимость дальнейших исследований в предметной области с учетом последних событий в Украине. Результаты исследования могут быть полезными для ученых и управленцев, исследующих проблемы национальной безопасности, развития сектора безопасности и обороны, оборонного планирования.

Ключевые слова: война, гибридная война, гибридные угрозы.

\title{
Analysis and systematization of approaches to understanding the concept of "hybrid war"
}

\author{
Anatolii Loishyn ${ }^{1}$ A; Ivan Tkach ${ }^{2}$; Mykola Tkach ${ }^{3}$ A; Vitalii Shevchuk 4 A \\ ${ }^{1}$ Corresponding author: PhD, Senior lector of Department of financial support, e-mail: aloishyn@gmail.com, ORCID: 0000-0003-2769-9336 \\ ${ }^{2}$ Doctor of Economics, Professor, Head of the Center, e-mail: tkachivan9@gmail.com_ORCID: 0000-0001-5547-6303 \\ ${ }^{3} \mathrm{PhD}$, Head of the Department, e-mail: nyck1985@ukr.net, ORCID: 0000-0002-8832-1268 \\ ${ }^{4} \mathrm{PhD}$, Chief of the Military Security Research Laboratory of the Strategy National Security and Defence Department, \\ e-mail: shevchuksnbo@ukr.net, ORCID: 0000-0002-8532-739x \\ A National Defence University of Ukraine named after Ivan Cherniachovskyi, 28, Povitroflotsky, ave, Kyiv, 03049, Ukraine
}

\begin{abstract}
The article summarizes the arguments and counterarguments within the scientific discussion on the phenomenon of hybrid warfare, taking into account the involvement of Ukraine in the Russian Federation in a state of undeclared hybrid war.

The study's main objectives are the analysis and systematization of approaches to understanding the nature of hybrid warfare by domestic and foreign scientists, generalization of its key features and formulation of a synthesized definition taking into account the ongoing aggression against Ukraine.

Based on the systematization of a wide range of scientific papers and approaches to solving the problem of studying the nature of hybrid warfare, scientists tend to increase the attention of scientists to its study. The urgency of solving this scientific problem in the Ukrainian dimension lies in the direct involvement of Ukraine in the plane of the undeclared war.

The issue of hybrid warfare in the article is studied in the following logical sequence: retrospectively analyzed the development, formation and identification of the content of the terms "hybrid war", "hybrid means of warfare"; the relationship between hybrid warfare, a wide range of its methods and tools; signs of hybrid war in several wars and conflicts are singled out; the tendencies to the regulation of hybrid warfare are analyzed not only in scientific sources, but also in normative-legal documents; approaches to determining the content and nature of hybrid warfare, which are reflected in the publications of domestic scientists, according to which a universal interpretation of the term is formulated, and the idea of its "umbrella" meaning is confirmed. The study's methodological tools were the methods of analysis, synthesis, and systematic approach; the time limits are partially covered by historical events from the Peloponnesian War to the present.

The study's object was war in all its manifestations because hybrid warfare is derived from ordinary conventional warfare.

The article presents an empirical analysis of approaches to understanding the nature of hybrid warfare, which show the need for further research in the subject area, taking into account recent events in Ukraine.

The study results can be useful for scientists and managers who study national security problems, development of the security and defence sector, and defence planning.
\end{abstract}

Keywords: war, hybrid war, hybrid threats. 


\section{References}

1. Carl von Clausewitz, On War, Michael Howard and Peter Parent, eds. and trans., Princeton, NJ: Princeton University Press, 1976, p. 77. See also Christopher Daase, "Clausewitz and Small Wars," in Hew Strachan and Andreas HerbergRothe, eds., Clausewitz in the Twenty-First Century, New York, NY: Oxford University Press, 2007

2. Trebin. M. P. Hibrydna viyna yak nova ukrayins'ka real'nist' [Hybrid war as a new Ukrainian reality]. Ukrayins'kyy sotsium. 2014. №3 (50). S. 113-127.

3. Hoffman, F. G. Conflicts in the 21st Century: The Rise of Hybrid Wars / Potomac Institute for Policy Studies. - Arlington, VA, 2007. P. 14.

4. "The Black Swan: The Impact of the Highly Improbable", The New York Times, by Nassim Nicholas Taleb, April 22, 2007.

5. Slovnyk ukrayins'koyi movy. Akademichnyy tlumachnyy slovnyk (1970-1980) [Dictionary of the Ukrainian language. Academic Explanatory Dictionary (1970-1980)]. URL: http://sum.in.ua/s/zmishanyj

6. Hodovanyk YE. V., Rusanevych A. T. Mizhnarodno-pravovi problemy "hibrydnykh" zbroynykh konfliktiv u suchasnomu sviti [International legal problems of "hybrid" armed conflicts in the modern world]. Visnyk mariupol's'koho derzhavnoho universytetu, seriya: pravo. 2017. №. 14. S. 56-68.

7. Svitova hibrydna viyna: ukrayins'kyy front : monohrafiya [World hybrid war: Ukrainian front: monograph] / za zah. Red. V. P. Horbulina. - Kharkiv : Folio, 2017. - $496 \mathrm{~s}$.

8. Walker, R. G. SPEC FI: the United States Marine Corps and Special Operations. Naval Postgraduate School. - Monterey, California, December 1998.

9. Huber, T. M. Compound Warfare: A Conceptual Framework //. Compound Warfare: That Fatal Knot/ Thomas M. Huber, ed.: US Army Command and General Staff College Press. Fort Leavenworth, KS, 2002. - P. 2.

10. Hoffman, F.G. Conflicts in the 21st Century: The Rise of Hybrid Wars / Potomac Institute for Policy Studies. - Arlington, VA, 2007. - P. 14.

11. Nemeth, W. J. USMC, Future War and
Chechnya: A Case for Hybrid Warfare / Naval Postgraduate School. Monterrey, CA, June 2002.

12. Hoffman, F.G. Retrospectives on the Future Security Environment, statement before the Subcommittee on Intelligence and Emerging Threats and Capabilities / House Armed Services Committee. - U.S. House of Representatives, February 13, 2012. P. 3.

13. Kurban O. V. Suchasni informatsiyni viyny $v$ merezhevomu on-layn prostori [Modern information wars in network online space]: navch. posib. Kyiv: VIKNU, 2016. 286 s. URL: http://www.mil.univ.kiev.ua/files/222_10442 84240.pdf.

14. McCuen John J. Hybrid Wars. Military Review. 2008. № 3(4). URL: http://www.au.af.mil/au/ awc/awcgate/milreview/mccuen08marapr.pdf

15. Poltorakov O. Hibrydna viyna $v$ konteksti asymetrychnoho svitoustroyu [Hybrid war in the context of asymmetric world order]. Zbirnyk naukovykh prats' "Hileya": Naukovyy visnyk. 2016. № 100, S. 258-259.

16. Gerasimov V. Tsennost' nauki v predvidenii [The value of science in foresight]. Nezavisimoye voyennoye obozreniye. 2013. № 8(476).

17. Reeves S. R. The New Griffin of War: Hybrid International Armed Conflicts / S. R. Reeves, R. E. Barnsby // Harvard International Review. Mode of access: https://www.questia.com/ library/journal/1G1-316203914/the-newgriffin-of-war-hybrid-international-armed. Title from the screen.

18. Fleming B. P. The Hybrid Threat Concept: Contemporary War, Military Planning and the Advent of Unrestricted Operational Art : Monograph / B. P. Fleming. - School of Advanced Military Studies United States Army Command and General Staff College Fort Leavenworth, Kansas. - AY, 2011. - 85 p.

19. Shevchuk V. V., Punda Yu. V. Mihratsiyna kryza yak skladova hibrydnoyi viyny [Migration crisis as a component of hybrid war]. Information and analytical activities in the field of security and defense. 2020. № 2(38). S. 95-100.

20. Kilcullen D. Out of the Mountains: The coming 
age of the urban Guerrilla / D. Kilcullen. Oxford. University Press.

21. Poltorakov O. Hibrydna viyna v konteksti asymetrychnoho svitoustroyu [Hybrid war in the context of asymmetric world order]. Zbirnyk naukovykh prats' "Hileya": Naukovyy visnyk. 2016. № 100, S. 258-259.

22. Gerasimov V. The Value of Science Is in the Foresight. Military Review. 2016. JanuaryFebruary. P. 23-29. (en).

23. Petryk K., Kanars'kyy YU. Metody hibrydnoyi viyny Rosiyi proty Ukrayiny [Methods of hybrid war of Russia against Ukraine]. Napryamy protydiyi. Information technology and security. 2015. № 3/1 (4). S. 30-37.

24. NATO's Bi-Strategic Command Capstone Concept, 5000 FXX/0100/TT-0651/SER: NU0040 Dated 25 August 2010.

25. Koval' Z. Informatsiyno-psykholohichna stiykist' yak stryzhen' stratehiyi protydiyi asymetrychnym (hibrydnym) viyna [Information and psychological stability as the core of the strategy of counteracting asymmetric (hybrid) war]. Aktual'ni problemy derzhavnoho upravlinnya. 2016. № 2(66). S. 59-63.

26. Fedenko O. V. Hibrydna viyna v Ukrayini yak faktor suchasnoyi kholodnoyi viyny dlya Rosiyi [Hybrid war in Ukraine as a factor of the modern Cold War for Russia]. Molodyy vchenyy. 2017. № 9 (49). S. 119-125

27. The Military Balance 2015. NY: The International Institute for strategic studies, 2015. $501 \mathrm{p}$.

28. Pro rishennya Rady natsional'noyi bezpeky i oborony Ukrayiny vid 14 veresnya 2020 roku "Pro Stratehiyu natsional'noyi bezpeky Ukrayiny" [On the National Security Strategy of Ukraine]: Ukaz Prezydenta Ukrayiny vid 14.09.2020 №392/2020.

29. Svitova hibrydna viyna: ukrayins'kyy front: monohrafiya [World hybrid war: Ukrainian front: monograph] / za zah. Red. V. P. Horbulina. - Kharkiv: Folio, 2017. 496 s.

30. Koval' Z. Informatsiyno-psykholohichna stiykist' yak stryzhen' stratehiyi protydiyi asymetrychnym (hibrydnym) viyna [Information and psychological stability as the core of the strategy of counteracting asymmetric (hybrid) war]. Aktual'ni problemy derzhavnoho upravlinnya. 2016. № 2(66). S. 59-63.

31. Steven Metz, Douglas Jonson. P.5 // Asymmetry and US Military Strategy: Definition Background and Strategic Concepts. Strategic Studies Institute, 2001.

32. Zhekalo H. I. Hibrydna viyna RF proty Ukrayiny: ekonomichnyy vymir [ybrid war of the Russian Federation against Ukraine: economic dimension]. Zbirnyk naukovykh prats' "Hileya: naukovyy visnyk". 2017. № 145. S. 47-51.

33. Zolotar O. O. Osoblyvosti informatsiynoyi bezpeky lyudyny $v$ umovakh hibrydnoyi viyny [Peculiarities of human information security in the conditions of hybrid war]. Informatsiya $\mathrm{i}$ pravo. 2017. № 3(22). S. 124-131.

34. Mahda YE. V. Hibrydna viyna : vyzhyty i peremohty [Hybrid war: to survive and win] / YE. V. Mahda. - KH. : Vivat, 2015. 304 s.

35. Pocheptsov H. Hibrydna viyna : Informatsiyna skladova [Hybrid war: Information component]. URL: http://osvita.mediasapiens. ua/trends/1411978127/gibridna_viyna_infor matsiyna_skladova.

36. Trebin M. Fenomen "hibrydnoyi viyny" [The phenomenon of "hybrid" war]. Hileya. 2014. Vypusk 87 (8). S. 366-371.

37. Trebin M. P. Hibrydna viyna yak nova ukrayins'ka real'nist' [Hybrid war as a new Ukrainian reality]. Ukrayins'kyy sotsium. 2014. № 3. S. 113-127.

38. Petryk K., Kanars'kyy YU. Metody hibrydnoyi viyny Rosiyi proty Ukrayiny [Methods of Russia's hybrid war against Ukraine. Directions of counteraction.]. Napryamy protydiyi. Information technology and security. 2015. № 3/1 (4). S. 30-37.

39. Shyyan A. A, Poplavs'kyy A. V., Nikiforova L. O., Zastup I. V. Model' rozrakhunku rivnya napruhy u suspil'stvi dlya pryynyattya efektyvnykh rishen' iz zakhystu natsional'noyi bezpeky [Model of calculating the level of tension in society to make effective decisions to protect national security]. Informatyka ta matematychni metody v modelyuvanni. 2018. № 8(4). S. 345-343. 
40. Sydorenko D. A. Hibrydna viyna yak suchasnyy sposib vedennya viyny [Hybrid warfare as a modern way of warfare]. Molodyy vchenyy. 2018. № 11 (63). S. 920-923.

41. Karpchuk N. Media yak nevoyennyy metod vplyvu $v$ hibrydniy viyni [Media as a nonmilitary method of influence in a hybrid war]. Suspil'ni komunikatsiyi. 2018. №2(4). S. 41-49.

42. Telelym V. M., Muzychenko D. P., Punda YU. V. Planuvannya syl dlya vykonannya boyovykh zavdan' u "hibrydniy viyni" [Planning forces to perform combat missions in a "hybrid war"]. Nauka i oborona. 2014. № 3. S. 30-35.

43. Alimpiyev A. M., Pyevtsov H. V. Osoblyvosti hibrydnoyi viyny RF proty Ukrayiny. Dosvid, shcho otrymanyy Povitryanymy Sylamy Zbroynykh Syl Ukrayiny [Features of the hybrid war of the Russian Federation against Ukraine. Experience gained by the Air Force of the Armed Forces of Ukraine.]. Nauka i tekhnika Povitryanykh Syl Zbroynykh Syl Ukrayiny. 2017. № 2(27). S. 19-25.

44. Radkovets' Yu. I. Oznaky tekhnolohiy "hibrydnoyi viyny" v ahresyvnykh diyakh Rosiyi proty Ukrayiny [Signs of "hybrid war" technologies in Russia's aggressive actions against Ukraine]. Nauka i oborona. 2014. № 3. S. 36-42.

45. Lipkan V. A. Sutnist' hibrydnoyi viyny proty Ukrayiny [The essence of the hybrid war against Ukraine]. URL: http://goalint.org/sutnist-gibridnoi-vijni-proti-ukraini/.

46. Datsyuk A., Poshedin O., Shypilova L. Strukturno-funktsional'nyy analiz bezpekovykh aspektiv polityky yevropeys'koyi intehratsiyi v umovakh protydiyi rosiys'kiy ahresiyi $v$ hibrydniy viyni proty Ukrayiny [Structural and functional analysis of security aspects of European integration policy in the context of counteracting Russian aggression in a hybrid war against Ukraine]. Teoriya i praktyka publichnoho upravlinnya. Zbirnyk naukovykh prats' NADU. 2019. № 1/2019. S. 61-68.

47. Hibrydna viyna: tekhnolohiyi suhestiyi ta kontrsuhestiyi [Hybrid war: technologies of suggestion and counter-suggestion: monograph]: monohrafiya / O. Akul'shyn, O. Zaruba, L. Kompantseva, S. Kudinov, N. Slukhay, O. Snytko. Kyyiv: Natsional'na akademiya SBU, 2018. $236 \mathrm{~s}$. 